\title{
Analysis on "Collusion": The Possibility of a New Type of Rent-seeking in the Separation System of Education Powers in China
}

\author{
Yangchun Sun, Anqi Xu \\ Graduate School of Education, Dalian University of Technology, Dalian, China \\ Email address: \\ 2003@163.com (Yangchun Su), uanqi1993@163.com (Anqi Xu) \\ To cite this article: \\ Yangchun Sun, Anqi Xu. Analysis on "Collusion": The Possibility of a New Type of Rent-seeking in the Separation System of Education \\ Powers in China. Higher Education Research. Vol. 4, No. 4, 2019, pp. 56-61. doi: 10.11648/j.her.20190404.13
}

Received: August 27, 2019; Accepted: September 12, 2019; Published: October 2, 2019

\begin{abstract}
Identifying and avoiding education rent-seeking is an important issue in improving the structure of education governance and establishing a modern education governance system. By using critical discourse analysis, his study attempts to explore rent-seeking within education powers under the separation system. "Collusion" is a new type of rent-seeking in education powers under the background of the separation of supervision, running and evaluation. Once it happens, it will bring serious hazards in governance. Moreover, collusion is overlooked easily. Previous research on education rent-seeking was mostly concentrated on rent-seeking of "monopoly power"; However, far too little attention has been paid to the rent-seeking of "union power" that may appear in the separation system of supervision, running and evaluation. Collusion is also known as conspiracy and complicity. The study found that the forms of collusion in education include the collusion between running and evaluation and the collusion between supervision and running. The "essence" of education collusion is to seek union rent in a more subtle form. Collusion in education may generate "potential hazards" of disrupting the cooperative order of honesty and trustworthiness, reducing the level of interaction and cooperation, gaining the short-term union but damaging the public interest ultimately, thus causing serious threats to the "benign interaction among supervision, running and evaluation".
\end{abstract}

Keywords: Power Rent-seeking, Collusion, Separation of Supervision, Running and Evaluation in Education

\section{Introduction}

One of the most important education reform events in China recently was the separation of government supervision, school running, and society evaluation, which was an important measure to deepen institutional reform in the field of education. In 2010, the "Outline of the National Mediumand Long-Term Education Reform and Development Plan (2010-2020)" in China was first proposed in the form of an official document to promote the separation of supervision, running and evaluation of education; In 2015, "Several Opinions on Deepening the Separation of Supervision, running and Evaluation and Promoting the Transformation of Government Functions" issued by China Ministry of Education also proposed to further promote the separation of supervision, running and evaluation. Thus, the separation reform of supervision, running and evaluation has entered a new stage of deepening reform from "why to separate" to "how to separate". Accordingly, recent research has heightened the need for "discovering the problems existing in the reform and solving them" rather than "stating the necessity of demonstrating reform", which is the practical way to help promote the reform.

So how can we promote the separation of supervision, running and evaluation and what are the threats and problems that may be faced in the separation reform of education powers? In the pages that follow, it will be argued that the collusion within education powers in the separation of supervision, running and evaluation is a major obstacle to rationalize the relationship of government, school and society, and also serious threats to the establishment of a benign interaction mechanism in these three powers. 


\section{What Does "Collusion" Mean in Education Powers}

Collusion was an ancient political and economic behavior that has existed for a long time in ancient Chinese. It was also called conspiracy and complicity, which refers to joint planning and secret negotiation. However, only in the past 100 years have studies directly proposed the concept of the academic term-collusion. In the 1920s, "collusion behavior" [1]was first investigated in the field of industrial organization; In the 1970s, American economist Stigler (1974) proposed the concept of "collusion" explicitly when studying Government Regulating Economics and Public Choice Theory [2]; It was not until 1986 that Tirole truly opened up the research of "organizational collusion" [3, 8] when investigating the collusion in bureaucracy; In 1992, Tirole further combed the research and formed the organizational "collusion theory" [4], which developed it into a kind of formal theory.

What does collusion mean? Tirole demonstrated that collusion referred to "an improper behaviour that caused two or more entities to collude with each other for the maximization of personal interests and that caused damage to the third-party's interests." Later, some scholars enriched the concept. Based on the definitions of Tirole and Villadsen (1995) [5], this paper further defines collusion as "the non-legitimate behavior of two or more entities seeking union interests through private unions and contracts". Such behavior often harms the interests of the third-party to promote a non-productive transfer of wealth. Different from cooperation, the characteristic elements of collusion are shown in Table 1.

Table 1. The difference between collusion and cooperation (Taking the collusion between running and evaluation as an example).

\begin{tabular}{lll}
\hline Running \& Evaluation & Collusion & Cooperation \\
\hline Union approaches & Private union & Open cooperation \\
Ways of earning profits & Deceptive, concealed & Honest, trustworthy \\
Working attitudes & Negative, shiftless & Active, hard-working \\
Beneficiaries & Good for both entities but harms the public interest & Good for both entities while increasing public interest \\
\hline
\end{tabular}

There were historical studies in the area of political, economic and other fields of society applied Collusion Theory since the emergence of it. For example, listed companies and auditors represented by the US Enron incident swindled financial report through "audit collusion" [6]; Local governments and state-owned enterprises exploit state-owned assets through "collusion between government and enterprises" [7]; Environmental audit institutions and enterprises conceal the degree of environmental pollution through "collective collusion" [8]. Similarly, here will be similar threats of "collusion" in education powers with the separation reform of supervision, running and evaluation.

\section{Collusion Phenomenon in Education Powers}

Collusion in reality can be divided into two types according to Laffont. One is the collusion between "two" agents and the other is "the collusion between the supervisor and the agent" [9].

One type of collusion exists between "two" agents. The collusion between the school and the evaluation agency can be abbreviated as "running-evaluation collusion". In order to obtain evaluation results that exceeds the true level of education quality, the school bribes the evaluation agency to provide false information, thus forming collusion. Running-evaluation collusion can easily occur in certain situations. A university ranking that has attracted attention on the Internet in recent years is a typical example: the university has twice invited the person in charge of the university ranking to make academic reports in the school. Since then, this university has risen rapidly in the ranking.
Coincidentally, the time when the university's ranking has risen sharply was also the time when the university paid sponsorship fees to the ranking agencies.

The other type of collusion exists between the supervisor and the agent. The collusion between the local government and the school can be abbreviated as "supervision-running collusion". Some local governments collude with local schools to help them to conceal their true school quality for local regional interests. The quality of education, especially the quality of universities, is also one aspect of the performances of local governments and plays a pivotal role in the political achievements as well as the image of local governments. Coincidentally, universities do not want to be exposed to their own unfavorable evaluation results. Therefore, once the evaluation results of the universities affiliated to the local government do not occupy superior position, the local government can easily reach an agreement and form a collusion with the university for the purpose of student resources, funding, and image.

The collusion exists in a potential form and happens at any time. If any two or three entities of supervision, running and evaluation do not work hard and form a union privately by means of bribe or bullying, it seems that the collusion entities can obtain short-term benefits, $\mathrm{n}$ the end, the collusion could damage the quality of education and teaching, the public interest of the state and the educated, and also bring serious difficulties in cooperation and governance, which is of destructive harm.

\section{The Essence of Collusion in Education Powers Is to Seek "Union Rent"}

As we all know, there is long-term power rent-seeking 
phenomena in the field of education, such as bribing and being bribed, capturing and being captured, false report and concealment. Theoretical research into rent-seeking in the field of education has also been involved, such as research conducted in China by WANG (2005), MAO (2006) and YANG (2007). So why should these seemingly identical phenomena be re-branded as collusion? Why does the collusion pose a serious threat to the benign interaction mechanism of three entities?

Fundamentally speaking, collusion is also a type of rent-seeking. Although it seems that the collusion is somewhat similar to traditional rent-seeking, in essence, they are very different. Collusion is often easily overlooked and has different reasons for formation and regulation ways. That is to say, "this kind of bribery" is not "the other kind of bribery" and "this kind of rent-seeking" is not "the other kind of rent-seeking". Precisely speaking, traditional education rent-seeking seeks monopoly rents while the collusion in education powers seeks the union rent.

\subsection{The Traditional Rent-seeking in Educational Power Seeks “Monopoly Rent"}

Monopoly rent refers to the rent of power formed by a entity with monopoly power to set rent so as to seek unjustified profits, which as the British historian Acton (1955) said, "All power tends to corrupt and absolute power corrupts absolutely" [10]. Krueger, a professor at the University of Minnesota in the United States, formally proposed the concept of "rent-seeking" on Political Economy of the Rent-seeking Society in 1974 [11]; Later, Tullock officially founded the Rent-seeking Theory. From the very beginning, the above research directly related rent-seeking with "monopoly power" [12] and considered rent-seeking as "an investment behavior that cannot increase output or even reduce output, but can bring special status or monopoly power to the entities" [13]. In education, here is a large volume of published studies attributing the generation of traditional education rent-seeking behavior, such as bribery, captive, bullying and fraud into monopoly power and "monopoly supply" [14]. Study by WANG and WANG (2005) showed the rent-seeking behavior in the process of choosing a school. They proposed the concepts of "seekers" and "renters" and believed that "as the education provider, the government and schools had a monopoly on the supply of education, and they obtained a large amount of rent" [15]; Study by HAO and MAO (2006) showed that the concentration of higher education management system was one of the root causes of education rent-seeking. They clearly stated that "the centralized higher education management system has caused extensive interference in higher education by the government and the education administration. Because of the large amount of educational resources, he government must become the object of rent-seeking for all types of rent-seeking entities" [16]; Also, study by WANG and YANG(2007) showed that rent-seeking phenomenon was mainly depended on the "the existence of so-called rent, the essence of which is the monopoly interest formed by the government" [17].

\subsection{The Collusion in Education Power Seeks "Union Rent" with the Supervision, Running and Evaluation}

"Union rent" [18] refers to the rent of power obtained by two or more entities by rejoining the separated powers in a private "aligned way" [19] to rent and seek unjustified income. According to the logic of the traditional rent-seeking theory, rent-seeking came from monopoly supply. Once the monopoly supply disappeared, monopoly power did not exist, and rent-seeking could not happen. Actually, instead of disappearing, rent-seeking power has just reappeared as another form, hat is collusion.

Collusion with the separation of education powers could be easily overlooked. When education powers are divided from "integrated" entity into "separated" entities, the powers of ownership, running and supervision are separated, which also represents that the ownership is not responsible for the running but the running entity is responsible to the owner, and the supervision entity plays the role of supervision and evaluation independently. It seems to be a perfect framework for mutual restraint and balance, therefore, or many years, the existence of collusion was surprisingly neglected in the early Principal-agent Theory. Since then, the fact that in a framework that looked like separation and checks and balances of powers, supply, production and evaluation are unable to fully grasp the information of each other. Consequently, these power entities "can't sign a complete contract" [20] to avoid moral hazard and adverse selection was gradually recognized until the development of the Incomplete Contract Theory [21]. At this time, power rent-seeking is manifested in the form of union rent-seeking, also known as "collusion". As Tirole discovered, in the framework of a principal, supervisor, and agent, collusion is the act of "agents even supervisors helping agents hide information to deceive principles". [3] In short, collusion is a kind of "strategic behavior" [22] - a "strategic behavior" [23] and "strategic choice" [24] that the entities chooses to unite for rent-seeking in the case that any power cannot rent alone, which is a new form of rent-seeking under the power-separation system.

"Union rent-seeking" was not fully recognized in the early days of the separation reform of supervision, unning and evaluation in China. Education rent-seeking research has attracted the attention since the $1990 \mathrm{~s}$, but there is little research on education rent-seeking in separation of supervision, running and evaluation. The main reason is that most scholars believe that centralized-power is the main reason for education rent-seeking. That is to say, as long as government monopoly in the supply of higher education is broken and the reasonable control boundary is defined, the power relationship in government, university and society can be straightened out. The implication is that as long as the separation of education powers is achieved and the monopoly supply of education is ended, a perfect framework for mutual checks and balances will be formed naturally, the phenomenon of rent-seeking, such as bribing 
and being captured, can be avoided naturally, even benign interaction in supervision, running and evaluation is the result that can be achieved naturally after the separation of powers. Therefore, since the beginning of the reform, number of Chinese authors have described the beautiful vision of decentralized governance. For example, "Governments, schools, and society adhere to their respective boundaries within the framework of the law, each performing their duties and returning to their positions, and jointly performing their respective functions" (ZHOU, 2014) [25]; "The three entities are relatively separated and mutually promoted, coordinated, and supervised with each other, forming a new pattern and system for education public governance with pluralistic co-governance, equal consultation, and win-win cooperation (SUN, 2015) [26]. The new pattern of governance after the separation of powers described by the above scholars is also aspired by all researchers and practitioners, including the author. However, it must be emphasized that in order to achieve such a fantastic vision, the issue of education rent-seeking, especially the new type of rent-seeking, cannot be avoided and must be taken seriously. Few research in the field of education rent-seeking in the separation of supervision, running and evaluation still put the reason of education rent-seeking on the traditional framework of monopoly rent-seeking, which considered that the concentration and monopoly, "insufficient market competition" [27] and the "uniform university governance model" [28] are still the main reasons for education rent-seeking behaviors. Obviously, "If there is only decentralization and no checks and balances, it is impossible to form a stable and reasonable power structure" [29]. Balanced and reasonable power structure "can effectively restrict the power penetration and rent-seeking" [29]. In short, in the separation of supervision, running and evaluation, he collusion in educational research is "ignored inappropriately" [3] as the principal-agent research in the early economic field.

\section{5. "Collusion" Will Pose Serious Threats on the Benign Interaction}

The real key to effectively deepening and promoting the "separation system of supervision, running and evaluation" is to achieve effective linkage and cooperation among three entities on the basis of separation and to build a benign interaction mechanism. However, once the potential collusion within the government, the school and the society occurs, it will pose a serious threat to the effective cooperation of the three sectors, and bring about a serious cooperation dilemma.

\subsection{Collusion will Disrupt the "Honest and Trustworthy" Cooperative Order of the Three Entities}

Collusion is an improper behaviour of seeking interests by means of "capturing \& being captured and bribing \& being bribed" [30]. The usual means is to form an alliance by means of false reporting through reaching an agreement or contract other than the law, so that both sides can obtain short-term benefits. Both "running- evaluation collusion" and "supervision-running collusion" can disrupt the benign order of higher education. The collusion between school and evaluation agency is that the school purchases the evaluation agency in private, so that the evaluation agency can provide evaluation results higher than its actual school-running quality. In addition, some local governments and schools form supervision- running collusion, which is the improper behavior of local governments helping school "conceal" their true school quality for the benefit of region performance. If such distorted information is published and issued for a long time, it will inevitably disrupt the open and legitimate cooperation. Even worse, once the false information published by the evaluation agency is used as a reference for decision-making, it will becomes a signal orientation guiding the school and the evaluation agency to continue collusion for false reporting. In the end, it will inevitably lead to the public losing confidence in the evaluation agencies and regulatory agencies. Integrity and non-trustworthiness will become the trend, and the benign order of honesty and trustworthiness will inevitably be destroyed.

\subsection{Collusion will Reduce the "Effort Level" of the Interaction Within the Three Entities}

As a professional term, "effort level" [31] has frequently appeared in the research of public goods supply in recent years, which specifically referred to the degree of emphasis on something or work formed by factors such as motivation and will, and an indicator to measure subjective cognizance. High-level efforts will lead to behaviors characterized by active efforts and hard work while low effort level will result in a behavior characterized by "demotivation, inaction, and laziness" [32]. Collusion Theory puts the research on how to improve the effort level in an important position. Research on the "effort level" in the field of education has also gradually emerged, such as "efforts level of government to fund in education" [33], "efforts level of local government to fund in higher education" [34], "efforts level of provincial governments to fund in higher education" [35], etc. From the assumption of rational economic man, collusion itself is a kind of opportunistic behavior, a strategic behavior to obtain the benefits of short-term alliances. If it is not regulated, it will inevitably lead to the typical consequences of laziness, demotivation, inaction and other low level of efforts. For example, if the school found that it can benefit from the "running-evaluation collusion", such as "improving" its school ranking, gaining much more government's resources and receiving widespread acclaim in recruitment and students employment, it will not choose to fight for the benefits through active efforts to run schools, improve teachers and teaching methods, and optimize educational content; Similarly, if it finds that it can get the government's fund in purchasing services as well as the rent provided by the school just by completing the evaluation task arranged by the 
government by the means of the "running-evaluation collusion", then it will not choose to benefit from the proper way of studying evaluation indicators, improving evaluation procedures, and investing a lot of energy in evaluation. Therefore, how to avoid the potential collusion risk of three entities, improve the efforts of the three sectors, and form the "logic of collective action" [36] within supervision, running and evaluation, will be an important proposition.

\subsection{Collusion Will Bring Short-term Alliance Benefits, but Ultimately Harm the Public Interests}

Collusion Theory holds that if the alliance between two or more powers is beneficial to the public interest, it is called cooperation; on the contrary, if it is detrimental to the public interest, it is called collusion. Collusion and cooperation are literally slightly different, but their actual meaning are vastly different: cooperation increases overall profits while collusion does not increase or even reduce overall profits.

According to Economics of Regulation, organizational interests are usually divided into two parts, one is "public interests" [37] or "overall interests" [38], the other is "department interests" [39] or "group interests" [40]. However, since the concept of "union rent" was put forward in Collusion Theory, "union interests" [41] or "alliance interests" [42] were added to the middle of "department interests" and "public interests" to form a chain of "department interests $\rightarrow$ union interests $\rightarrow$ public interest". Judging by the definition of collusion, the short-term union interests formed by collusion are beneficial to both entities of the collusion. However, the "union interest" formed by collusion is only a "non-productive transfer" of interests, which transfers the public interest to the interests of the department and the union department in a way that harms the public interest. In fact, it has not increased or even reduced the overall benefits. That is what Tarlock called "an act that does not increase or even reduce output" [13]. For the supervision, running and evaluation powers of education, schools and evaluation agencies can obtain short-term interests on the surface in "running-evaluation collusion". For example, a school only needs to pay some rent to bribe the evaluation agencies can it get the funds invested by the government without spending the cost on running to improve the quality and education level. The evaluation agency can obtain the investment of the government's purchase evaluation service without consuming the cost to develop indicators, hiring experts, or conducting on-the-spot evaluation. Besides, it can also obtain the rent given by the school. It seems that the harvest is greater than the pay, and the income is greater than the cost, which is beneficial to both entities, but fundamentally, this kind of collusion not only defrauds the state's financial resources, reduces the level of education and teaching, impairs the quality of personnel training, but also disrupts the order of supervision, and ultimately harms the public interest of the state and the educated. In short, there is nothing to gain and is extremely harmful.

\section{Conclusion}

Just as the issue of collusion after the "separation of ownership and control" [10] in 1932 in the economic field was concerned, collusion inevitably arises due to the existence of the third party power from the beginning of the separation of supervision, running and evaluation in education. This study has provided a deeper insight into the possibility of collusion in the separation system of education powers in China. Collusion, with different formation reasons and regulation ways compared to traditional education rent-seeking is a new type of rent-seeking under the separation reform of supervision, running and evaluation. The insights gained from this study may be of assistance to the problems and reform directions in the reform of the education system.

The rationalization and benign interaction within the government, the school and the society cannot achieve overnight because potential collusion will affect or even threaten to manage the effective cooperation of the three entities. Therefore, collusion should come into our research field. Due to the concealment of collusion behaviour, collusion will jeopardize the order of governance and damage the public interest seriously.

In short, in order to address the above issues, it is necessary to explore and take effective measures. Weakening the motive of collusion, increasing the cost of collusion, educing the collusion profit, and improving the incentive regulation contract are all feasible ways that can be tried to avoid collusion, which would be a fruitful area for further research.

\section{Fund Project}

Research on Moral Risk Avoidance of Third-Party Education Evaluation under the Separation System of Supervision, Running and Evaluation, a General National Project of Education Science Planning(Project No. BIA170163).

\section{References}

[1] Jian-Bing LUO. Generation and Checks and Balances of Collusion [M]. An Hui: Hefei University of Technology Press, 2008: 18 .

[2] Stigler, G. J. The Free Riders and Collective Action: An Approach to the Theories of Economic Regulation [J]. Bell Journal of Economics and Management Science, 1974, 5 (2): 360 .

[3] Tirole, J. Hierarchies and Bureaucracies: On the Role of Collusion in Organizatio [J]. Journal of Law, Economics, \& Organization, 1986, 2 (2).

[4] Tirole, J. Collusion and the Theory of Organizations $[\mathrm{M}] / /$ Tirole, J., \& Laffont J. J. Advances in Economic Theory: Proceedings of the Sixth World Congress of the Econometric Society Cambridge: Cambridge University Press, 1992: 71. 
[5] Villadsen, B. Communication and Delegation in Collusive Agencies [J]. Journal of Accounting and Economics, 1995, 19 (2): 335 .

[6] Guang-Yong LEI. Economic Analysis of Audit Collusion [J]. Journal of Audit \& Economics, 1999 (2): 23.

[7] Hui-Hua NIE, Jin-bo LI. Collusions between Governments and Firms and Economic Development $[\mathrm{J}]$. China Economic Quarterly, 2007 (1): 75.

[8] Li-Long HE, Zhong-Wei CHEN, Jie ZHANG. Collusion and Supervision in Environmental Pollution: A Game Analysis [J]. Qinghai Social Sciences, 2009 (1): 33.

[9] Laffont, J. J., Martimort, D. Mechanism Design with Collusion and Correlation [J]. Econometrica, 2000, 68 (2): 315.

[10] Acton, J. E., Himmelfarb, G. Essays on Freedom and Power [M]. Ohio: World Publishing Company, 1955: 556.

[11] Krueger, A. O. The Political Economy of the Rent-Seeking Society [J]. American Economic Review, 1974: 64 (3): 291.

[12] Chamberlin, E., Jia-Lin GUO. The Theory of Monopolistic Competition [M]. Beijing: SDX Joint Publishing Company, 1958: 63.

[13] Tullock, G. The Welfare Costs of Tariffs, Monopolies, and Theft [J]. Economic Inquiry, 1967, 5 (3).

[14] Harberger, A. C. Monopoly and Resource Allocation [J]. American Economic Review, 1954, 44 (2): 78.

[15] Li WANG, Shan-mai WANG. Behavior Analysis of School Rent-seeking Subjects in Compulsory Education [J]. Education Science, 2005 (6): 6.

[16] Bao-Wei HAO, Ya-Qing MAO. Rent- Seeking in Higher Education [J]. Tsinghua Journal of Education, 2006 (5): 21.

[17] Feng-E WANG, Ke-Rui YANG. Public Power and Education Rent-seeking [J]. Contemporary Education Sciences, 2007 (11) 12

[18] Connolly, R. A., Hirsch, B. T., Hirschey, M. Union Rent Seeking, Intangible Capital, and Market Value of the Firm [J]. Review of Economics and Statistics, 1986, 68 (4): 567.

[19] Hirsch, B. T. Market Structure, Union Rent Seeking, and Firm Profitability [J]. conomics Letters, 2004, 32 (1): 75.

[20] Hart, O., Moore, J. Property Rights and the Nature of the Firm [J]. ournal of Political Economy, 1990, 98 (6): 1142.

[21] Grossman, S., Hart, O. D. The Cost and Benefits of Ownership: A Theory of Vertical and Lateral Integration [J]. The Journal of Political Economy, 1986, 94 (4): 691

[22] Kreps, D. M., Wilson, R. Reputation and Imperfect Information [J]. Journal of Economic Theory, 1982, 27 (2): 256.

[23] Chun-Hui GAN, Yu-Lin YAO. The Frontier of Strategic Behavior: A Survey [J]. hina Industrial Economics, 2005 (11): 118

[24] Salop, S., Scheffman, D. T. Raising Rivals'Costs [J]. American Economic Review, 1983, 73 (2): 267.

[25] Hai-Tao ZHOU. Separating the Government Authorities, Management and Assessment in Higher Education: Reasons and Approaches [J]. ournal of National Academy of Education Administration, 2014 (3): 5.

[26] Xiao-Bing SUN. Promote the Separation of Supervision, Running and Evaluation, and Build a New Pattern of Education Public Governance [J]. hina Higher Education, 2015 (20): 9.

[27] Xi-Ping HAN, Hai-Long QU. Features, Reasons and Solutions of Rent-seeking in Education [J]. ournal of Northeast Normal University (Philosophy and Social Sciences), 2014 (4): 153.

[28] Xiao-Ming ZHANG. Rent-seeking and Regulation of Higher Education-Also on the Reform of University Governance in China [J]. hina Adult Education, 2015 (3): 12.

[29] Duan-Wu TU. Power Structure Evolution in the Transformation of Chinese Higher Education Administration System [J]. Modern University Education, 2006 (1).

[30] Stigler, G J, Zhen-Min PAN. The Organization of Industry [M]. hanghai: Shanghai People's Publishing Press, 1996: 90.

[31] Akerlof, G., Yellen, J. . The Fair Wage-Effort Hypothesis and Unemployment [J]. uarterly Journal of Economics, 1990, 105 (2): 268

[32] Laffont, J J, Tirole J. ei SHI. Incentive Theory in Government Procurement and Regulation [M]. hanghai: Truth \& Wisdom Press, 2014: 451.

[33] Ze-Yun LIU. An empirical analysis on the effort to fund education of Chinese government during the Ninth Five-Year Plan [J]. Journal of Higher Education, 2003 (2): 61.

[34] Hui-Min QIN, Cheng YANG. The Effort to Fund Higher Education of Local Government [J]. Journal of National Academy of Education Administration, 2013 (7): 73.

[35] Quan-Zhi YAN, Qian-Qian ZHANG. Empirical Study on the Effort to Fund Higher Education of Provincial Government [J]. Education \& Economy, 2010 (3): 17.

[36] Olson, M, Yu CHEN. The Logic of Collective Action [M]. hanghai: Shanghai People's Publishing Press, 1995: 14.

[37] Feintuck, M., Xin DAI. The Public interest' in Regulation [M]. Beijing: China Renmin University Press, 2014: 3.

[38] Feng YANG. A Normative Analysis of Government Supervision: A Review of Traditional Public Interest Theory and Its Policy Application [J]. Economic Review Journal, 2007 (12): 78.

[39] Fu-Liang CHEN. Government Rules: Views and Comments on Public Interest Theory and Sector Interest Theory [J]. ournal of Jiangxi University of Finance and Economics, 2001 (1): 21.

[40] Feng YANG. Departmental Interest Theory and New Regulation Economics [J]. ianghuai Tribune, 2008 (5): 5.

[41] Dong-Chuan SUN, Fei YE. The Research for the Negotiation Model about the Benefit Allocation of the Dynamic Alliance [J]. cience Research Management, 2001 (2): 91.

[42] Le-Bin XING, Xu WANG, Hong-Bin XU. Research on Risk Compensation of Benefit Distribution of Industrial Technology Innovation Strategic Alliance [J]. tatistics \& Decision, 2010 (14): 63.

[43] Berle, A., Means, G. C. The Modern Corporation and Private Property [M]. ew York: MacMillan. 